\title{
Integrating Content and Language in Business English Teaching in China: First Year Students' Perceptions and Learning Experience
}

\author{
Elaine Ruth Martyn ${ }^{1}$ \\ ${ }^{1}$ School of English for International Business, Guangdong University of Foreign Studies, Guangzhou, China \\ Correspondence: Elaine Martyn, School of English for International Business, Guangdong University of Foreign \\ Studies, 2 Baiyun Avenue North, Guangzhou, China. Tel: 185-6540-9223. E-mail: ma.yiling@yahoo.com
}

Received: June 9, 2018 Accepted: July 20, 2018 Online Published: July 22, 2018

doi: 10.5539/elt.v11n8p86 URL: http://doi.org/10.5539/elt.v11n8p86

\begin{abstract}
Content and language integrated learning (CLIL) is a key construct in Business English teaching in universities in China today. While there is a plethora of articles on implementation in European contexts, there is limited evidence in the literature of the teaching/learning experience in other foreign language learning environments - despite its wide application in, for example, south-east Asia and China in particular. As CLIL programs have been developed in a variety of ways to meet the unique needs of learners and societal expectations, the context of teaching and learning is critical. This paper focuses on the perceptions and learning experiences of students in a first year, first semester course, Introduction to Contemporary Business, in a Chinese university. Lesson observations, questionnaires, and interviews explore the experience of learners. While most students found the course very challenging in their first semester, they met the challenge. Coping with both language and content is always a double challenge: most students found their Introduction to Contemporary Business their most difficult course, yet they perceived it as manageable and worthwhile. Students coped with the difficulty level in two main ways: either by spending much time in review and translating the textbook prior to class, or by focusing on the teacher's PowerPoint slides after class - as they considered these were the key points and the textbook was too difficult. Suggestions for a closer integration between language and content within CLIL courses are offered, such as a case-task-based approach, a greater variety of input, and the role of content teachers in English enhancement.
\end{abstract}

Keywords: bilingual education, business English, China, CLIL, content and language integrated learning, L2 medium instruction, student perceptions

\section{Introduction}

Content and language integrated learning (CLIL) has developed as an important cross-disciplinary program in China over the past few decades. In fact, as noted by Zhu and Deng (2015, p. 159), "Business English education has evolved into ... one of the hottest majors pursued by students and professionals." In China, as around the world, research on CLIL programs has most often reported positive outcomes, particularly in terms of language learning; it is now generally recognized that these English medium programs also face significant challenges, in terms of content learning and students' overall learning experience.

Background information on English as a dominant world language, China's business English programs, and CLIL research, frame the discussion of a case study of one first year CLIL course, Introduction to Contemporary Business, in the School of English for International Business (SEIB) at Guangdong University of Foreign Studies (GDUFS). After an overview of the research participants and methodology, this paper focuses on student perceptions (and attitudes) and their learning experiences, challenges faced, and strategies used by students to cope, based on classroom observations, survey data and individual comments in interview discussions. The paper closes with a summary and recommendations to enhance the implementation of CLIL classes in Business English in China.

\section{The Context}

The context of CLIL in business English teaching must be considered from the macro to the micro level: world-wide, in China, the University, and the classroom - as all levels impact on the motivations, attitudes, and experiences of Chinese learners of business English. 


\subsection{World-Wide}

The power of English in education, business, and politics "has reached unprecedented heights of global importance" (Costa \& Crowther, 2018, p. 19). Grado (2006) and Crystal (2008) "have claimed that 75\% of English speakers are now not only 'nonnatives' (NNSs) - equaling nearly two billion users - but that $75 \%$ of face-to-face English interactions are between NNSs" (cited in Costa \& Crowther, 2018, p. 19). English as a global lingua franca has drawn many universities in countries to teach full programs in English although English is neither the national language, nor a colonial inheritance (as, it is, for example, in Hong Kong or India). As indicated by Jensen and Thøgersen (2011, p. 18) regarding English medium instruction in Denmark, "Proponents of an increased use of English in university teaching, whether they are politicians, academics, political commentators or others, focus their arguments on the internationalisation of university programmes." While the first stated purpose is usually to enhance graduates' competitiveness in the international job market - as in Denmark, or to build the nations' economy - also emphasized in China; two other considerations are also key: to attract highly-ranked foreign academics and to draw in foreign students (economic benefit).

\subsection{China}

Vigorous promotion of English in China, whether identified as CLIL, English medium of instruction (EMI) or bilingual education, has primarily been envisioned as crucial to national development. As noted by Feng (2007, p. 2): "To meet the challenge of globalisation and economic growth, the country longs for Zhuanye Waiyu Fuhexing Rencai (human resources who possess both knowledge in specialised areas and strong competence in a foreign language) or Guojixing Rencai (international talents)."

Feng (2007) noted a lack of clarity in the model of bilingual education appropriate to various Chinese institutions in terms of how it should be implemented in the classroom, most often referring to the language of text books, and teachers' and students' use of English vs. Chinese. A lack of clarity of policy seems to continue to the present day. However, in the interest of enhancing Interdisciplinary knowledge, the Chinese Ministry of Education has recently specified that in the Business English curriculum, English language learning courses should occupy $50 \%-60 \%$ of students' study; business knowledge, $20 \% \sim 30 \%$; cross-culture communication and humanistic quality, $5 \% \sim 10 \%$; and the final year project and professional practice $15 \%$ (Zhu, Lin, \& Zhu, 2016, p. 137).

\subsection{SEIB at GDUFS}

In 2007 the application of Guangdong University of Foreign Studies to set up the first Business English undergraduate program in China was approved by the State Council and the National Ministry of Education. Zhu, $\mathrm{Wu}$, and Guo (2009, p. 31) describe the integration of language and content as the use of "original English teaching materials taught by the teacher in both English and Chinese, and with class discussions, assignments, presentations, examinations and dissertations done by the students in English". Further, in this university, the authors emphasize the uniqueness of the teachers, most of whom possess at least two degrees, one in English language and literature, and a higher degree in a business-related subject (management, economics, law, etc.). In addition, a high proportion - at the time of this study and now - have earned their postgraduate degrees in English-speaking countries, and some have work experience in businesses. This range of experience of local staff plus foreign teachers (for example, eight foreign teachers in 2016-2017) enables the department to effectively implement the business English program. An early review by Zhu et al. (2009) highlighted its positive outcomes: $96 \%$ of students passed the TEM 8 examination (a Test for English majors in China) and almost a $100 \%$ percent employment rate of graduates on leaving the university from 2004-2008. Also $37.8 \%$ of graduates obtained positions in highly recognized foreign companies (e.g., PriceWaterhouse, P\&G), or Chinese government agencies, state-owned banks/commercial banks, or airlines. Positive outcomes, similar to these, are still evident.

A comparison of TEM 4 (taken in the second semester of year 2, i.e., the $4^{\text {th }}$ semester) and TEM 8 (taken in year 4 , the $8^{\text {th }}$ semester at university) from 2015-2017 shows that students of SEIB score a much higher pass rate than the national average of all foreign language universities. SEIB students' pass rate on TEM 4 was $21.5 \%$ higher than the national average of all foreign language university students; this difference increased to $29.7 \%$ for the TEM 8 . These differences, especially the increase from TEM 4 to TEM 8 , may reflect the effectiveness of the model of teaching and learning within the school.

Recently, some researchers in the department, in line with developments in CLIL world-wide, have begun to focus more specifically on the learning outcomes, teaching approach, and students' perceptions while others are exploring the development of business English from a more theoretical perspective (Cai, Wang, \& Yang, 2018; Dai \& Cai, 2017; Ouyang, Zhu, \& Liu, 2017; Zhu et al., 2016). A review of four recent papers aims to establish the teaching and research context of the School. 
Cai et al. (2018) compared learning outcomes in an accounting course involving 1104 second year students over a six-year period, including students from SEIB with non-English majors in a dual degree program from other schools in the University, to "examine the role language proficiency plays in understanding the content of an accounting course and to investigate what may influence accounting learning" (p. 58). The two groups enrolled in the university based on their National University Entrance Exam (Gaokao) were at the same standard level, but differed in entry English proficiency and hours of English language teaching as the English majors had intensive English classes during their first two years of study. Both groups (English and non-English majors) were taught in English by the same teacher using the same textbooks and teaching methodology. Statistical analysis of data on student assessments and a survey of career plans were carried out. Students' performance on a case report, was based on how students responded to the case questions:

One question tests how well they understand the case and the other two test their ability in applying what they have learned in class to analyzing the case. Reading comprehension, writing and analysis skill take up $20 \%, 20 \%$ and $60 \%$ of the total score respectively. (Cai et al., 2018, p. 54)

As predicted by the researchers, there appeared to be "no direct significant relationship between accounting learning and students' English proficiency" (p. 58). Instead, students' analytical skill, attitude, and career path determined their success. These results convinced the authors that English immersion teaching at college level was effective, regardless of whether they receive intensive language study as English majors. And this also raises questions about delaying content knowledge teaching for Business English majors - rather than offering such courses in their first year at university.

Dai and Cai (2017) integrated the case study approach common in business courses with the task-based approach of English language teaching to focus students' attention on both language and content in an authentic classroom setting in a marketing course. The authors outline and illustrate a six-stage teaching and learning process: "(1) theoretical knowledge preparation (2) case preparation, (3) case analysis, (4) case presentation, (5) case summary, [and] (6) case report writing" (p. 25). The application of the approach is clearly illustrated, followed by advantages and some difficulties in implementation. Three strengths identified are improving students' communication skills, enhancing students' listening and collaborative skills, and bridging the gap between theory and practice in a real-world business environment (p. 28). Problems encountered included demands on students' English comprehension (language proficiency) and conceptual understanding (business knowledge), and on teachers' time in identifying and developing appropriate cases that are not too complex. To address these issues, it is suggested that besides improving their language skills, students should also read materials in Chinese, while teachers need to refine case design to make the cases more accessible to students as well as improve communication between teachers and students. This approach to integration of content-based approaches (use of cases) should be lauded; however, a greater focus on principles of task-based approaches should also be considered.

Zhu, Lin, and Zhu's (2016) survey completed by 68 students in SEIB at GDUFS explores students' attitudes and perceptions of studying in the business English program. Though the total number of respondents to the online survey is not high, they represent all four years of study and a range of business English, specializing in economics, finance, management, law, trade, and international business. The dominant reason given for choosing GDUFS was career prospects $(47.06 \%)$, and in line with the students' priority for learning practical business skills (36.76\%) and business English (33.82\%), with lower ratings in all questions on general/academic English and business theories (pp. 133-135). Although business and English have a high priority in the program, the results indicate that students feel they lack practical business skills $(50 \%, 69.57 \%$ of final year students) and business language skills [English] (39.71\%, \% for year 4 students not given) (p. 136). In response to a question on degree of satisfaction with the current design of business English courses, $66.18 \%$ gave a neutral response, $16.18 \%$ indicated they were satisfied, while $17.65 \%$ were not. Interestingly, when asked to identify the most significant obstacles in their study experience, $58.82 \%$ selected "finding a suitable way of study"; $42.65 \%$, understanding content; and $32.35 \%$, vocabulary. Students and the authors suggest a stronger and earlier focus on business courses (and specializations). In addition, the authors recommend teaching business in Chinese, and enhancing English communication opportunities in both classes and extracurricular activities involving foreign students studying at the university. Surprisingly, students' concern about "finding a suitable way to study" is not directly addressed.

More theoretically, Ouyang et al. (2017) explore the motives of the Chinese business English development model based on the theory of human capital. Developing from previous research in China on human capital and investment in education, and a limited number of published articles on the teaching of Business English in terms of human capital and linguistic/educational economics, this paper explores the rapid expansion of business 
English degree programs in China from one approved undergraduate programs (at GDUFS) in 2006 to over 50 in 2016 (Ministry of Education website, cited in Ouyang et al., p. 18). Business English education investment and advantages apply to both the individual and the society; however, the authors focus on motives at the individual student level, considering family influence and social position. They contend that student/family investment in time and money results in unique advantages for graduates who enter the competitive job market better prepared, because of the complementary model of "'English + Professional' multi-skilled talents who are better in business knowledge than general English major graduates and who are better in English proficiency than business management major graduates" (p. 23). In summary, they conclude, "business English graduates enjoy higher education investment returns, stronger family influences, and a higher social position, which together interpret and justify the motives of quick development of the BE degree program with the theory of human capital" (p. 23).

Each of the four papers summarized offers a unique perspective on the business English program at SEIB by focusing research on exploring motives and attitudes, identifying needs and outcomes, and enhancing the learning experience of students in the classroom. This paper continues the focus on exploring and identifying the most effective means of enhancing student learning in a CLIL context in China.

\section{Content and Language Integrated Learning (CLIL)}

CLIL, the term used in this paper, but variously identified in the literature as content-based instruction, immersion, or bilingual education, was coined in Europe in the early 1990s in a supporting bid to unify the European Union, enhance multilingualism, and enhance the prospects of both nations and individuals. As English has become the international lingua franca whereby speakers of different languages interact with one another for business, academic, political, and personal purposes; there is an increasing demand for more effective teaching and learning of the language.

Sylvén (2017, p. 51) described CLIL as "a means to increase learners' exposure to a target language (TL), by using it as the medium of instruction to other school subjects, in order to facilitate the learning of that language." This integration of teaching of language and content is believed by many to limit the additional time and cost that would be required to do each separately, but also to motivate learners and engage them in meaningful communication - as favored by communicative and task-based learning advocates. The true value of CLIL is the the potential for active learning which "transcend[s] the isolation that sometimes characterizes language learning" in "a context [of] authentic, meaningful communication" (Georgiou, 2012, pp. 495-496). Unfortunately, research indicates that there is often very little integration of the language and content, and the positive enthusiasm evident in earlier papers is now tempered by awareness of conflicting results on outcomes and a greater focus on specific features, such as classroom discourse/interaction, pragmatics, and impacts on the learning of content knowledge, not only language (Morton \& Llinares, 2017, p. 2).

\subsection{Positive Impacts}

As early as 2000, Marsh made strong claims for the benefits of CLIL in terms of children's language learning and attitude. Similarly, Wolff (2007, p. 23) claimed "(1) it produces better language learners, (2) it produces better content learners and (3) it creates motivation for teachers as well as students". As noted by Cenoz (2017), CLIL is always more challenging than simply a language or content course, yet the higher contact hours in the target language may counterbalance this and lead to positive gains in language proficiency.

\subsection{Concerns}

Positive gains have been noted by numerous studies (see Marsh, Pérez Cañado, \& Ráez Padilla, 2015); however, in higher education, the concern (and research) has shifted towards a greater emphasis on content learning. The first recommendation noted by these authors is "qualitative case studies and classroom observation, on-theground praxis should be scrutinized and described in order to provide more comprehensive data and draw possible patterns on what CLIL looks like in practice" (Marsh et al., 2015, p. 5).

Amidst ongoing expansion of CLIL programs world-wide (which would seem to point to their effectiveness), there are repeated concerns in the literature regarding teachers' and students' competency to deal with content knowledge in their L2 - which need to be studied, clarified, and addressed. CLIL teachers' lack of competence to teach effectively in their second language (most often English), has been identified as a constraint in several studies, especially in language environments where teachers and students often share the same L1 (Costa \& Coleman, 2013; Jensen \& Thøgersen, 2011; Lasagabaster \& Sierra, 2009 as cited in Costa \& Coleman, 2013, p. 5). In a study of lecturers switching from Swedish to English teaching, Airey (2011) found lectures were more superficial, less precise, and slower, with more repetition and less content. Their teaching style changed with less 
examples and jokes, less fluency and even affected their body language. But it must be emphasized the study took place within a training course designed to help them adapt to teaching in English; with additional preparation and experience, it would seem likely that such effects would be less pronounced. And again, the question arises, are the students and teachers really "killing two birds with one stone"? Is the outcome worth the effort?

Students' language competency has also been questioned, that is, whether students' limited L2 proficiency will impair their understanding of content in a CLIL context (Jensen \& Thøgersen 2011, p. 21). Cai, Wang, and Yang (2018) summarize concerns from China-based articles that point to reduced learning in content knowledge, but several others that demonstrate success, particularly with students who have passed CET 4, suggesting that there may be a proficiency threshold for effective learning in higher education. For example, Chang and Liu (2014, cited in Cai, Wang, \& Yang, 2018) noted enhanced proficiency in English while level of understanding of business was maintained in GDUFS.

\subsection{More in-depth Studies of CLIL}

The role of the teacher is also noted as significant with Du's (2005, cited in Cai et al., 2018, p. 53) analysis of five roles of teachers in English immersion teaching: "instructor of the English language; disseminator of program-related content knowledge; provider of teaching and learning materials; facilitator of turning students' mind from language learning to program-related content learning; and promoter of the English language and culture and cultural exchange." And the study of Cai et al. (2018) seems to indicate that all else being equal, higher language proficiency or intensive language study may not be essential. Nonetheless, the nagging question remains: are teachers able to offer a flexible and interactive teaching environment in their L2, and are students able to participate actively in classroom interaction due to limited productive skills or lack of self-confidence, not just whether they have the listening comprehension skills to follow lectures (Airey, 2011; Jensen \& Thøgersen, 2011).

Feng (2007) focuses on the importance of contextualizing case studies and conceptual analysis. In the case of China, when using English textbooks, are students able to understand the application of their business courses in their own environment? And is there sufficient emphasis on current and relevant materials that students can relate to.

\section{Motivation in CLIL}

As proposed by Dörnyei (2009), the L2 Motivational Self System (L2MSS), has three distinct but inter-related components: (1) the ideal L2 self, (2) the ought-to L2 self, and (3) the L2 learning experience. And each of these impacts on the learning experience of students. To this structure, Ushioda (2009) adds the person-in-context relational view of motivation. She states,

many factors influenc[e] individuals and thus their language learning processes, and emphasizes the need to view learners not merely as language learners, but as people in a much wider context. Some of the factors to take into account are the global use of English as a lingua franca, the present-day mobility of individuals worldwide, and the increased availability of communication technology. Such factors reciprocally influence one another in intricate ways, and in order to say anything about a person's state of motivation, it is important to look beyond language related factors... Together with the L2MSS, this person-in-context framework seems particularly applicable in a CLIL context, in that language learning is ongoing in several subjects during the school day, and not merely reserved for the L2/FL classroom." (cited in Sylvén, 2017, p. $53)$.

Clearly, learning English as a second or an additional language may be seen as a basic skill, such as literacy numeracy, and ICT-necessary for the $21^{\text {st }}$ century, and this fits nicely within the CLIL concept, (Dalton Puffer, 2011).

Interestingly, motivation studies in CLIL have produced mixed results. As early as 2000, Marsh in a booklet, An Introduction to CLIL for Parents and Young People (Marsh, 2000, p. 2), claimed that "[CLIL] can be very successful in enhancing the learning of languages and other subjects, and developing in the youngsters a positive 'can do' attitude towards themselves as language learners"; but as Dalton-Puffer (2011) points out, later research does not offer evidence of this level of commitment and success in use of the English. Students who choose a CLIL course/program are already more highly motivated. But, it must be remembered that learning another language takes a long time: it is a time and energy consuming process and learner motivation tends to decrease over time as shown in studies by Cenoz (2001) Davies and Brember (2001), and Heining-Boynton and Haitema 
(2007 as summarized by Sylvén (2017, p. 54), and thus the question arises, what motivates learners to succeed and how can teachers keep up the momentum?

Possible motivators in CLIL include the concept of future self, authentic learning experience, and the individual, and even the national context. The subject taught, in this case English for business, may be critical: from the L2MSS perspective, the ideal L2 self and the language learning experience are both critical. In exploring Dörnyei's motivational concept, Sylvén (2017, p. 54) comments,

The ideal self is stimulated when the learner is forced to communicate real content, namely the subject he/she is trying to learn. In doing so, the learner may experience a possibility of a future self, able to effortlessly discuss intricate topics having to do with his/her profession, towards which the present education is the path.

In contrast, the English classroom may cause anxiety as the learner cannot meet the expectations of the ought-to self, with its focus on language. In a content subject, students can experience authenticity and by focusing their attention on content or real language use, they may face less stress language-wise. And herein lies the value of CLIL. By focusing on the content tasks, students are using language with, perhaps, less concern for language, as teachers focus on the content not the expression or manner of presentation in, for example, oral presentations. As noted in Canadian immersion research, even relationships with peers and teachers affect learners' success. Wesely's (2009) study shows the significance of the micro or classroom context" (see Dörnyei, 2003). It includes relationships with both teachers and other students and peers both within and outside of an immersion program, and it was found that the influence on language learning motivation could be both positive and negative.

MacIntyre, Baker, Clément, and Donovan (2003) discuss the concept of 'willingness to communicate' (WTC) and they speculate that the novelty at the early stages of immersion may increase motivation, though as they note motivation may decline in later years. Peng (2007), in a study of college students attending an intensive language program in China, found L2 WTC correlates with integrative motivation. Of the three components studied, motivation was the strongest predictor of L2 WTC, followed by integrativeness. Attitudes toward the learning situation did not appear to predict L2 WTC. These findings matched those of MacIntrye et al.'s (2003) earlier study but in an EFL not an ESL context. Thus, it could be argued that motivation is a key impetus in stimulating learners to persevere in both L2 learning and L2 communication-leading to effective L2 learning. However, as noted by Sylvén $(2017$, p. 60$)$ there may be a difference between how students are treated (and act) in relation to their use of English between EFL and CLIL classes. In the EFL classroom, students may be regarded as language learners, while they are considered as competent language users, perhaps even on par with the teacher, in a CLIL class. This acceptance could lead to their more successful language expression in the CLIL classroom.

In both CLIL and regular English language classrooms, teachers need to consider ways to motivate learners, by drawing them into new sorts of learning activities. And thus, the role of tasks in motivation in the CLIL classroom deserves greater exploration. As noted by Dörnyei (2002, pp. 140-141), from a process-oriented perspective, tasks can be motivational at three points: (1) in the pre-actional stage, motivation is generated by choice of goal (and in CLIL, perhaps program of study), (2) in the actional stage, executive motivation needs to be intentionally maintained (so, a teacher in the classroom can support this stage), and (3) in the post-actional stage, a motivational retrospection takes place, influences the learner's level of motivation going forward. In CLIL this refers to choosing a program of study, courses taken and reflections on learning. CLIL offers increased opportunities for language use. The CLIL task approach allows for increased motivational need in a real context, where using the language for a purpose (other than learning the language) can stimulate the ideal L2 self in a relevant and authentic context (Sylvén, 2017, p. 55). The case-task approach recommended by Dai and Cai (2017) seems to fit this priority.

\section{Calls for Research}

The literature on CLIL has recently focused on the need to explore more in-depth context-specific teaching and learning as in the 2017 book, Applied linguistics perspectives on CLIL edited by Llinares and Morton (2017). Even within the European context, Dalton-Puffer and Nikula (2014) have focused on the need to study "the beliefs, perceptions, motivations and orientations of both teachers and students ... [and] how those directly involved experience CLIL" (p. 118), but also the perspective of those outside of Europe who are following the CLIL model. Thus, this study embraces the teaching and learning experience of undergraduate students in China.

\section{Method}

This study uses triangulation to gain a clear perspective on the experiences of first year (first semester) students taking a content course, Introduction to Contemporary Business. Data was collected via questionnaires completed by students, interviews of students and teachers, and classroom observations. 


\subsection{Participants}

Participants in this study were 72 first year students in the first semester of a Business English program: this represents approximately $50 \%$ of the cohort. Six of these, who offered to participate, were also interviewed. Two teachers, who taught the three classes of the target course were also interviewed and agreed to me attending their classes for the observation.

\subsection{Sampling Procedures}

First, teachers agreed to be interviewed and observed, and they encouraged their students to complete the questionnaire. Study monitors (i.e., student leaders) distributed and collected all questionnaires from their classmates. Students who gave their names and contact details were contacted after the course completion to participate in an interview. Interviews (individual or group) were held in a small café in the library on campus. The only 'payment' to interviewees was a cup of tea or juice.

\subsection{Questionnaire Design}

The questionnaire was divided into three parts: background, motivation and attitude, and learning experience.

\section{Results}

The following summarizes the questionnaire results supplemented with comments based on interviews and classroom observations. Questionnaires were completed by 72 students in the second half of the semester.

\subsection{Students' Background}

The students began learning English between 2 and 13 years old, with a mean age of 7.1 years, and $80 \%$ between 6 and 10 years old. Only $20.8 \%$ ever had a private tutor, and only $16.7 \%$ have a close relative (i.e., parent, sister, brother, aunt, or uncle) who speaks English. This means that few had any strong personal contacts who spoke English, so their learning was school-based. Table 1 gives students' responses to the question, "Who/What influenced you to study English?" (multiple answers allowed).

Table 1. Influences to study English $(\mathrm{N}=72)$

\begin{tabular}{lll}
\hline Influence & Number of students & \% of students \\
\hline Parents/family & 22 & 30.6 \\
Friends & 24 & 33.3 \\
Personal interest & 50 & 69.4 \\
Future career & 48 & 66.7 \\
Other*/No particular reason & 10 & 13.9 \\
\hline
\end{tabular}

*Note. Two students mentioned a teacher.

Clearly, the most significant influences were personal interest (indicated by $69.4 \%$ of respondents) and future career $(66.7 \%)$, though this idea must be tempered by the fact that almost half of the students $(48.6 \%)$ indicated personal connections (parents, family and/or friends) were influential in their choosing to pursue English studies. It should also be noted that a few interviewees indicated that they had not originally intended to study English or business when they were in high school, but their Gaokao scores were not high enough to be accepted into highly ranked Chinese universities in their fields of interest, so they decided to study at GDUFS, because they liked English, and GDUFS is viewed well.

\subsection{Motivation and Attitude}

Future-oriented motivators to study English, attitudes to English, reasons for studying at Guangdong University of Foreign Studies, and images of their future selves were further explored to better understand students' responses to studying the CLIL course. Students' future-oriented motivation was addressed with the question, "What motivates you to study English?" (See Table 2). 
Table 2. Future-oriented motivators for studying English $(\mathrm{N}=72)$

\begin{tabular}{llll}
\hline Motivators & Disagree & Neutral/ & Agree/ \\
I want to ... & Strongly disagree & Don't know & Strongly agree \\
\hline - $\quad$ travel and make contacts abroad. & 4.2 & 4.2 & 91.7 \\
- $\quad$ study abroad. & 9.7 & 30.6 & 59.7 \\
- $\quad$ work abroad. & 12.5 & 44.4 & 43.1 \\
- work in an international company in & 1.4 & 15.3 & 83.3 \\
China. & & & \\
\hline
\end{tabular}

Note. Ratings of agree and strongly agree are combined; ratings of disagree/strongly disagree are combined.

The strongest motivator identified by students is travel and contacts abroad with $91.7 \%$ of respondents choosing this option; however, a high percentage want to work in China for an international company (83.3\%). So, study $(59.7 \%)$ or work (43.1\%) abroad would likely be temporary or short-term.

Students' attitudes to English were measured with four positive and one negative statement as shown in Table 3.

Table 3. Attitudes to English (N=72)

\begin{tabular}{llll}
\hline Attitudes & $\begin{array}{l}\text { Disagree } \\
\text { Strongly disagree }\end{array}$ & $\begin{array}{l}\text { Neutral/ } \\
\text { Don't know }\end{array}$ & $\begin{array}{l}\text { Agree/ } \\
\text { Strongly agree }\end{array}$ \\
\hline 1. I like communicating in English. & 2.8 & 18.1 & 79.2 \\
2. English is important in the world today. & 2.8 & 0.0 & 97.2 \\
3. English is useful in business. & 1.4 & 2.8 & 95.8 \\
4. English is boring to study. & 79.2 & 8.3 & 12.5 \\
5. English is valuable for my future career.* & 1.4 & 2.8 & 94.4 \\
\hline
\end{tabular}

Note. Ratings of agree and strongly agree are combined; ratings of disagree/strongly disagree are combined.

* One student gave no response to this statement.

The respondents view English as very significant in the world, in business, and in their future careers. Interestingly, the number of students who agreed that they like communicating in English perfectly matches the number who strongly disagreed that "English is boring to study" $(79.2 \%)$. Students also rated their reasons for studying at GDUFS (See Table 4).

Table 4. Reasons for studying at GDUFS

\begin{tabular}{llll}
\hline Opportunity to study ... & Total & Mean score & $\mathrm{N}$ \\
\hline$-\quad$ English & 308 & 4.27 & 72 \\
- business & 281 & 3.96 & 71 \\
- both English and business at the same & 300 & 4.23 & 71 \\
time. & & & \\
\hline
\end{tabular}

Note. Other reasons were given by 20 students, most often, in addition to their ratings.

The mean scores indicate students' interest in studying English and business, i.e., the SEIB focus drew them to the program - though other factors such as location, interpersonal connections, or perceptions of the institution, may have played a role in their decision-making. Another way to look at the responses is given in Table 5. 
Table 5. Reasons for attending GDUFS ( $\mathrm{N}=71)$

\begin{tabular}{lll}
\hline Ratings comparison & Number & $\%$ \\
\hline High ratings overall & 56 & 78.9 \\
$>\quad$ Agree (4 or 5) for all 3 scores: English, business, and both & 7 & 9.9 \\
Higher interest in English & & \\
$>\quad$ Rating of 4 or 5 (agree) in English/ rating of 2 or 3 in business or both & 3 & 4.2 \\
Higher interest in business \\
$>\quad$ Rating of 4 or 5 (agree) in business or both/ rating of 3 in English \\
$\begin{array}{l}\text { Low ratings overall } \\
\quad \text { All ratings 1-3 }\end{array}$
\end{tabular}

Note. Ratings of agree and strongly agree are combined; ratings of disagree/strongly disagree are combined.

What attracted most students to the university and the program was the combination of learning English and business together. This means CLIL is of special importance. Double the number of students showed a higher interest in English than business, but the total was still less than $10 \%$ of respondents. Interviews clearly confirmed this dual interest, which matches the goals of the program.

When asked "What is your vision of yourself in five years?", students' ratings show their imagined self, their perceptions of their success and their confidence in themselves and their study in the program. The 5-point Likert scale is reduced to 3 ratings in Table 6 by combining Strongly disagree/Disagree and Agree/Strongly agree.

Table 6. Future self $(\mathrm{N}=72)$

\begin{tabular}{|c|c|c|c|c|}
\hline \multirow[b]{2}{*}{$\begin{array}{l}\text { When I think of myself in } 5 \text { years, I think of } \\
\text { someone who ... }\end{array}$} & \multicolumn{3}{|c|}{$\%$} & \multirow[b]{2}{*}{ Mean } \\
\hline & $\begin{array}{l}\text { Strongly disagree/ } \\
\text { Disagree }\end{array}$ & Don't know & $\begin{array}{l}\text { Agree/ } \\
\text { Strongly agree }\end{array}$ & \\
\hline 1. who can speak very good English. & 1.4 & 4.2 & 94.4 & 4.47 \\
\hline 2. who travels a lot. & 12.5 & 27.8 & 59.7 & 3.72 \\
\hline 3. who has a good job. & 1.4 & 16.7 & 81.9 & 4.26 \\
\hline 4. who has friends all over the world. & 8.3 & 29.2 & 62.5 & 3.75 \\
\hline 5. who is successful. & 0.0 & 38.9 & 61.1 & 3.86 \\
\hline $\begin{array}{l}\text { 6. who works in a company_-in China and } \\
\text { abroad.* }\end{array}$ & 1.4 & 11.3 & 87.3 & 4.17 \\
\hline
\end{tabular}

Note: One student did not answer this question question 6 so $\mathrm{N}=71$ for it.

Students highest rating of their future self was for their skills in English: 94.5\% viewed themselves as speaking "very good English" (Mean = 4.47) —which suggests a high degree of confidence in their English language learning ability and the program. Also notable is students' belief in their future career. Almost $82 \%$ agreed they would have "a good job" (Mean $=4.26$ ) and over $87 \%$ agreed to the statement that they would work "in a company -in China and abroad" (Mean = 4.17). Though the mean scores for travel, international friendships and success are lower: (below 4), the percentage of agree and strongly agree are still quite high - about $60 \%$. Perhaps disappointing is that only $25 \%$ strongly agreed that they would describe themselves as successful. Is this modesty or is one year beyond university not long enough for them to expect success?

\subsection{Learning Experience During the Course}

Students learning experience is explored through their identification of course aims, perceptions of language use, usefulness ratings of learning activities, and overall perspective on studying the course in their first semester, and difficulty ratings. 


\subsubsection{Student Aims}

Students were asked to rate their learning aims for the course in terms of English and business. Out of 72 respondents, $97.2 \%$ agreed with the statement "to improve my English" (agree: 31.9; strongly agree: 65.3\%); 97.2\% agreed with the statement "to improve my English" (agree: 31.9; strongly agree: 65.3\%) while 98.6 agreed with the statement "to learn about business'. Thus, although students were unfamiliar with the term CLIL, they certainly viewed their aims as balanced between the two components (English and business).

\subsubsection{Language of Teaching and Learning}

During the researcher's classroom observations, teaching was exclusively in English (with a few points translated to Chinese on PowerPoint slides presumably to aid the link to personal knowledge). Nonetheless, students were asked to estimate the percentage of English and Chinese used in the classroom and related outside activities. Mean scores show students' perceptions (Table 7). Student discussion in response to teacher-initiated interactions appeared to be more in Chinese, based on limited observation of classes, though students estimated a higher level of English usage.

Table 7. English vs. Chinese in teaching/learning in the course $(\mathrm{N}=72)$

\begin{tabular}{|c|c|c|}
\hline \multirow{2}{*}{$\begin{array}{l}\text { Time spent in Chinese vs. English when studying } \\
\text { Introduction to Contemporary Business. }\end{array}$} & \multicolumn{2}{|c|}{$\%$} \\
\hline & English & Chinese \\
\hline 1. By the teacher during class & $89.5 \%$ & $10.5 \%$ \\
\hline 2. By the teacher after class & $46.1 \%$ & $59.9 \%$ \\
\hline 3. By students during class & $73.6 \%$ & $26.4 \%$ \\
\hline 4. By students outside of class & $27.7 \%$ & $73.3 \%$ \\
\hline
\end{tabular}

According to students' estimates, within the classroom, English dominates with the mean indication of $89.5 \%$ of teacher talk in English and 73.6\% of student interaction in English. In interviews, students said that they spoke in English when points were course-related content, but used Chinese to give more personal comments. After class, however, they indicated that both teachers $(46.1 \%)$ and students $(27.7 \%)$ used much less English. Some interviewees said they never spoke to the teacher after class due to time constraints and personal unwillingness or confidence in approaching the teacher, but instead asked their classmates for clarification. Clearly, both teachers and students see the importance of English as the medium of instruction. After class whether with teachers or peers, Chinese dominates - as a means of communication and enrichment of students' understanding.

Further, the question arises: do students see integration between their English courses and their first content course? The next set of questions addresses their perception of a relationship between the course, Introduction to Contemporary Business, and other English courses or learning. As Table 8 shows, students' learning experience in this course enhances both their knowledge and motivation.

Table 8. Business knowledge and English learning $(\mathrm{N}=72)$

\begin{tabular}{lllll}
\hline & \multicolumn{4}{c}{$\%$} \\
\cline { 2 - 4 } Studying Introduction to Contemporary Business in English ... & $\begin{array}{l}\text { Strongly } \\
\text { disagree/ } \\
\text { Disagree }\end{array}$ & $\begin{array}{l}\text { Don’t } \\
\text { Know }\end{array}$ & $\begin{array}{l}\text { Agree/ } \\
\text { Strongly } \\
\text { agree }\end{array}$ & $\begin{array}{l}\text { Mean } \\
\text { rating }\end{array}$ \\
\hline 1. enhances my knowledge / understanding of business & 1.4 & 8.5 & $\mathbf{9 0 . 1}$ & 4.4 \\
2. helps me to understand the business world* & 1.4 & 2.8 & $\mathbf{9 5 . 8}$ & 4.4 \\
3. enhances my English skills & 0.0 & 9.9 & $\mathbf{9 0 . 1}$ & 4.4 \\
\hline 4. motivates me to improve my English & 1.4 & 12.5 & $\mathbf{8 6 . 1}$ & 4.2 \\
5. has motivated me to improve my English* & 4.2 & 5.6 & $\mathbf{9 0 . 3}$ & 4.3 \\
6. motivates me to improve my business knowledge & 1.4 & 12.9 & $\mathbf{8 5 . 7}$ & 4.3 \\
\hline
\end{tabular}

Note: Numbers 2 and 5 were asked in the context of comparing this CLIL course with other English courses. A few very similar questions were asked earlier and later in the survey to ensure reliability. 
The percentages and mean ratings in Table 9 emphasize students' perception of agreement to the statements on learning business and English (both 90.1\%) — though when asked about 'understanding the business world', the percentage rose over 5 points. Motivation to improve in both areas is also notable (close to $86 \%$ ). Interestingly, again, when asked about motivation in the broader context of other courses taught in English, the percentage rose almost 5 points.

Table 9. Relating the CLIL course to other English courses ( $\mathrm{N}=72)$

\begin{tabular}{|c|c|c|c|c|}
\hline \multirow[b]{2}{*}{ CLIL course relationship with other courses } & \multicolumn{3}{|l|}{$\%$} & \multirow[b]{2}{*}{$\begin{array}{l}\text { Mean } \\
\text { rating }\end{array}$} \\
\hline & $\begin{array}{l}\text { Strongly } \\
\text { disagree/ } \\
\text { Disagree }\end{array}$ & $\begin{array}{l}\text { Don't } \\
\text { Know }\end{array}$ & $\begin{array}{l}\text { Agree/ } \\
\text { Strongly } \\
\text { agree }\end{array}$ & \\
\hline $\begin{array}{l}\text { 1. Studying Introduction to Contemporary Business helps me to } \\
\text { understand other English courses. }\end{array}$ & 5.6 & 27.8 & 66.7 & 3.9 \\
\hline $\begin{array}{l}\text { 2. Studying other English courses helps } \mathrm{me} \text { to understand } \\
\text { Introduction to Contemporary Business. }\end{array}$ & 6.9 & 22.2 & 70.8 & 3.9 \\
\hline
\end{tabular}

Table 9 shows students gave lower ratings to a synergistic view of the relationship between learning this business course in English and other English language courses they were studying - which would seem to be an important aspect of the course from a CLIL perspective. However, over two-thirds of the students see the courses as supportive of one another.

\subsubsection{Learning Activities}

Figure 1 shows student perceptions of the usefulness of various course activities on their learning of English (upper bar) and business content (lower bar) based on mean ratings for each of the items. Clearly, all learning activities were rated as useful, with the lowest mean rating being $4.1(1=$ strongly disagree / $5=$ strongly agree $)$.

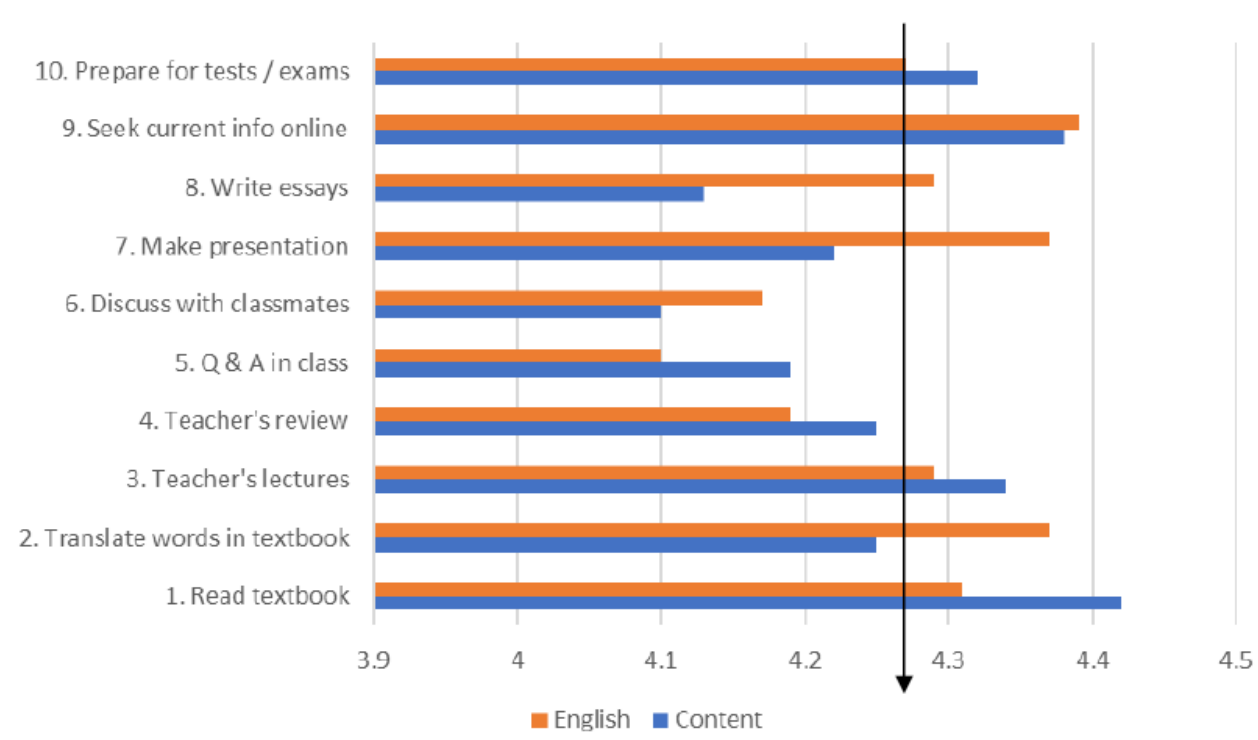

Figure 1. Usefulness rating of learning activities $(\mathrm{N}=72)$

The highest mean rating for content learning activity is reading the textbook (mean over 4.4), followed by seeking current information online. For English, interestingly, the highest rating is given for 'seeking current information online', followed by translating words and making presentations (equal), reading the textbook, and then teacher's lectures and writing essays. Interestingly, students gave higher ratings of more learning activities useful for English learning than content learning. Interview comments indicate that the book and teacher lectures were viewed as a means of conveying information. Checking up-to-date articles online was significant; yet interviews suggest a divide between those who felt confident in overall understanding, versus those who spent 
their time in preparing for the class knowledge. Those who grasped the basic content, then felt free to pursue online reading for application, while those who were least confident in understanding the course did not follow teacher recommendations for more recent or relevant illustrations of key components of content. This would seem counter-productive as students could have more easily understood the concepts with real life examples, yet due to time pressures did not do so as they concentrated more on reading and translating in preparation for the next class. Surprisingly, when asked what else they did to improve their English/business knowledge in the questionnaire, few students mentioned reading business-related topics; rather they mentioned videos and general English learning activities.

Students' perceptions of the major focus of the course is important as it helps one determine if the course is more business or English oriented - a balancing challenge in all CLIL courses. Students see the courses' emphasis on business and English as almost equal: in response to the statement: "the major focus of the course is English language/business knowledge" with an almost equal rating (English language: 4.5; business knowledge: 4.6) on the 1-5 Likert scale from strongly disagree to strongly agree.

\subsection{Overall Perspective on Studying Introduction to Contemporary Business in the First Semester}

The following section focuses on students' individual perspective on studying this CLIL course in first semester of the first year. Table 10 provides respondents overall ratings on studying the course.

Table 10. Studying a CLIL course in the first semester $(\mathrm{N}=72)$

\begin{tabular}{|c|c|c|c|c|}
\hline \multirow[b]{2}{*}{ About Introduction to Contemporary Business in English: } & \multicolumn{3}{|l|}{$\%$} & \multirow[b]{2}{*}{$\begin{array}{l}\text { Mean } \\
\text { rating }\end{array}$} \\
\hline & $\begin{array}{l}\text { Strongly } \\
\text { disagree/ } \\
\text { Disagree }\end{array}$ & $\begin{array}{l}\text { Don't } \\
\text { Know }\end{array}$ & $\begin{array}{l}\text { Agree/ } \\
\text { Strongly } \\
\text { agree }\end{array}$ & \\
\hline $\begin{array}{l}\text { 1. It's good to study Introduction to Contemporary Business during my } \\
\text { first semester at university. }\end{array}$ & 15.3 & 9.7 & 75.0 & 3.9 \\
\hline $\begin{array}{l}\text { 2. The course, Introduction to Contemporary Business, has met my } \\
\text { expectations for learning. }\end{array}$ & 11.1 & 19.4 & 69.4 & 3.8 \\
\hline $\begin{array}{l}\text { 3. The course, Introduction to Contemporary Business, has met my } \\
\text { learning needs. }\end{array}$ & 9.7 & 20.8 & 69.4 & 3.8 \\
\hline $\begin{array}{l}\text { 4. I feel I have been successful in learning the course, Introduction to } \\
\text { Contemporary Business. }\end{array}$ & 26.4 & 23.6 & 50.0 & 3.4 \\
\hline
\end{tabular}

Note: Totals for numbers. $2 \& 3=99.9$-due to rounding.

Here student ratings would suggest some uncertainty regarding their learning in the course, though in other questions students seemed very satisfied. While $75 \%$ of students thought it was good to study this course in first semester, less than $70 \%$ felt it met their expectations or needs. The success rating of students was the lowest: only $50 \%$ indicated they felt they were successful in learning. The mean of 3.4 shows their lack of confidence in their learning. However, at this point it may have been more fear and uncertainty, as they had only completed some of the term assessments, and had not yet taken the examination. However, the students who were interviewed (after the course was finished), offered a similar perspective.

\subsection{Course Difficulty}

As this was the first time that the course, Introduction to Contemporary Business, had been offered to students in their first semester of their first year in the business English program, a key question was: how difficult would students find it. Clearly, they saw it as more difficult than other English courses.

Students were asked to rate the difficulty of the course in three ways: Agreement to a statement which said it was difficult, a direct difficulty rating (from very easy to very difficult), and a comparison to other English courses (from much easier to much more difficult). One can see a lot of similarity in their ratings in Table 11. The 5-point Likert scale is simplified to three rating levels 
Table 11. Difficulty ratings $(\mathrm{N}=72)$

\begin{tabular}{|c|c|c|c|c|}
\hline \multirow[t]{2}{*}{ Ratings } & \multicolumn{3}{|c|}{$\%$} & \multirow[t]{2}{*}{$\begin{array}{l}\text { Mean } \\
\text { rating }\end{array}$} \\
\hline & $\begin{array}{l}\text { Strongly disagree/ } \\
\text { Disagree }\end{array}$ & Don't know & $\begin{array}{l}\text { Agree/ } \\
\text { Strongly agree }\end{array}$ & \\
\hline \multirow[t]{2}{*}{$\begin{array}{l}\text { 1. Studying Introduction to Contemporary } \\
\text { Business English in English is difficult. }\end{array}$} & 35.2 & 16.9 & 47.9 & 3.3 \\
\hline & $\begin{array}{l}\text { Very easy/ } \\
\text { Easy }\end{array}$ & OK & $\begin{array}{l}\text { Difficult/ } \\
\text { Very difficult }\end{array}$ & \\
\hline \multirow[t]{2}{*}{$\begin{array}{l}\text { 2. How would you rate the difficulty level of } \\
\text { this course? }\end{array}$} & 1.4 & 56.9 & 41.7 & 3.4 \\
\hline & $\begin{array}{l}\text { Much easier/ } \\
\text { Easier }\end{array}$ & Similar & $\begin{array}{l}\text { More difficult/ } \\
\text { Much more } \\
\text { difficult }\end{array}$ & \\
\hline $\begin{array}{l}\text { 3 How would you compare the difficulty } 9.7 \\
\text { level of this course to other courses you } \\
\text { study in English? }\end{array}$ & & 23.6 & 66.6 & 3.6 \\
\hline
\end{tabular}

Note. No. 1: $\mathrm{N}=71$. No. 3 TOTAL percent is 99.9 due to rounding.

Interestingly, students answered these three questions in somewhat different ways, perhaps related to the specific wording or placement in the questionnaire. Number 1 mentions English and occurred in the middle of the questionnaire; number 2 does not mention English and was at the end of the questionnaire; number 3 asks for a direct comparison and was also located at the end of the questionnaire. It would seem by comparing the three ratings about half of the students found studying the course in English difficult (though 35\% disagreed); almost $57 \%$ rated the level was acceptable (OK); nonetheless, two thirds found it more difficult than other English courses - which take up the majority of their class time.

Overall, students' perceptions of course difficulty varied greatly. Interviews clarified one likely cause of this. Some students had studied business in high school: they said they understood the concepts, and just needed to concentrate on learning the English terminology. Representing those who found it rather difficult, student interviewees indicated spending many hours (10-15 per week) to prepare for classes, and yet said though they had learned the key language necessary, they did not feel they understood the underlying concepts. Nonetheless, only one student said she wished she had been able to study the course in Chinese, while another indicated she wished the teacher had given more explanation in Chinese. While many students were concerned with their lack of in-depth understanding, teachers were satisfied: teachers saw the course as offering just a systematic overview of key topics in business - which would be further developed in future years, and they said students performed generally as well in the final (multiple choice) examination as in previous years.

How did students cope with the challenges of the course? Two main approaches were identified in the interviews. Some students described long hours of preparation, especially translating words in the text book, and sometimes checking online for Chinese explanations of concepts. Others, who did not want to spend so much time in preparation, tended to focus primarily on understanding the PowerPoint slides after class, as they found the textbook too difficult. Other strategies commonly employed were asking the teacher or classmates for further explanations.

\section{Discussion and Recommendations}

After a brief summary of the research, this paper concludes with recommendations for enhancement of CLIL in business English teaching.

\subsection{Summary}

Personal motivation and future orientation were cited as major factors in program enrollment, and continue to drive students' efforts in study. The strongest future-oriented motivators for English studies identified were an interest in travel and contacts abroad, and a desire to work in an international company in China. Interestingly, students showed less enthusiasm for studying or working abroad.

Students clearly see English as important in the world and useful in business-demonstrating a very pragmatic orientation. Their reasons for studying at SEIB show a similar predisposition in their selection of a joint business 
and English program. Also, students' envisioned self in five years indicates a positive view of their own success and confidence in their future, particularly in terms of their English skills and employment expectations to work in an international company.

Students' interest, commitment, and goal orientation can be seen in their positive ratings of the course in terms of both English and business, though two-thirds of students rated the course as more difficult than other courses. Nonetheless, most view this as an opportunity, not a stumbling block. Students perceive the CLIL course as enhancing both business and English skills and knowledge, and thus perceive the additional challenges as manageable.

Responses to questions concerning the study of Introduction to Contemporary Business in their first semester are positive. They reported it met their learning expectations and needs, but only half felt successful in learning. This could represent the challenge they felt in studying a subject which for most was unfamiliar, and the timing of the questionnaire completion in the second half of the semester. However, this sense of a lack of depth of understanding of business concepts and theories was confirmed in interviews held early in the second semester. This corresponds to the concerns of Jensen and Thøgersen (2011) and Cai et al. (2018), but not the teachers of the course who targeted only a broad knowledge base.

Students' responses to the learning experience demonstrate an appreciation of traditional teaching methods, with high ratings for textbooks, translation, examination preparation, and lectures; but also, an active learning approach in their use of modern technology (e.g., checking Chinese websites to enhance understanding of topics, and reading relevant up-to-date news in both English and Chinese) and participation in case studies and oral presentations. This demonstrates a pragmatic mixing of traditional and new methods of study, and both dependent and more autonomous means of learning.

Of particular interest to this researcher was students' responses regarding the integration of learning in business and English, i.e., not only within this course, but across the program. Responses to questions on the integration of learning, (studying a content course / studying English courses) suggest they are not aware of any synergistic effect across courses, which is a key point of CLIL. This could be due to the focus of each different course and the limits of integration at program level or simply students' (or even teachers') perceptions of courses as largely independent entities.

Thus, while students responded positively to Introduction to Contemporary Business, their first CLIL course, and formal test results for SEIB demonstrate the program's success in meeting national language standards; this study has identified some concerns as well as means to overcome challenges faced by learners.

\subsection{Recommendations}

As recently noted by Sylvén (2017, p. 61), "The gap between theory and practice [of CLIL] needs to be bridged, and one fundamental aspect is the creation of specific CLIL curricula and goals in which integration between language and subject content, and between subjects is pivotal."

Content, language, and teaching approaches need to be better integrated: the following four suggestions are based on students' suggestions and concerns.

The case-task study approach, as discussed in Dai and Cai (2017), illustrates how a case study business teaching approach, can be melded with a task-based language teaching approach. Surprisingly, Dai and Cai's paper makes little mention of key principles of task-based teaching, such as scaffolding, active learning and, integration of language skills, that should also be considered. Several students mentioned an appreciation of inclusion of case studies as they make manifest theory through example, but other peer collaborative tasks could also be explored (Léon-Henri, 2015). However, to truly benefit from a task-based approach, students need to encounter comprehensible input and learn how to negotiate meaning in English in real time in the classroom (See Costa \& Crowther, 2017; Zhu \& Wan, 2015) (See Cai et al. (2018) regarding the role of students).

A greater variety of input or text types, such as newspaper articles or news clips from BBC (British Broadcasting Corporation) or CGTN (China Global Television Network) would enhance learners' interest and engagement. This could also help to address (or create a platform for discussion) of differences in understanding and application of certain business principles, topics, and issues due to differences in culture, politics and legal systems in China and other countries - aspects which have confused some students from time-to-time. In addition, more focus on reading recent articles could provide theory and application in a more accessible, easier-to-read format. Unfortunately, some students do not follow-up on teachers' reading suggestions, citing the already heavy reading workload - in preparation for the next class. If such materials were recommended before the class and integrated into the class, this would likely engage more students. 
Two strategies to enhance student content understanding were suggested by a few students in interviews. More direct interaction with the teacher in class time was recommended by a few interviewees. One suggested that monitors could collect questions from other students after class, and the teacher could answer them the following week--since some students were reticent to raise questions themselves. Another said that Chinese could be used more in class to explain the most difficult but key concepts. However, students and the teachers accept the orthodoxy of an (almost) English-only classroom. Used judiciously and for limited periods of time, Chinese can enhance efficiency and clarity of key concepts (Zhu \& Wan, 2015), but this is a contentious issue. Of relevance here is students' concern about learning/study strategies identified in the research of Zhu, Lin, and Zhu (2016).

A greater focus on English language and presentation skills would emphasize the integrated nature of learning: This should begin at the program and course planning level, so there are clear learning objectives for language as well as content. Content teachers, most of whom have a background in ELT, could offer specific feedback on language and skills when students make presentations, and perhaps a small portion (10\%) of an assessment grade could be given for language. Or, teachers could give brief information on word usage and collocation when a new concept is introduced. Though the focus is on content in a CLIL course, and there is a risk that students could lose the confidence-building benefit of being an English user, meaning-focused interaction is critical to enhancing students' productive skills. It is exactly in this context that students' imagined future-self can be realized in the present, though too great a focus could lessen the benefit of students as users rather than learners of English (Sylvén, 2017).

This paper is a case study of one CLIL class in one university in China, yet the issues raised arise in many contexts, not only in China, but around the world. Each teacher or researcher needs to consider their particular context, but also relate their experiences to others, and thus I offer a few final comments.

I strongly support the comment made by Bannegas (2013): there is a need for collaboration between English and content teachers, including English teachers of content courses. Greater communication between teachers of different courses could lead to a more integrated overall student learning experience. Language and skills taught in one course could be applied in another. While some students naturally apply knowledge learned across courses, many seem to compartmentalize their learning, lessening the benefits of cross-fertilization. For example, if teachers in a language course knew that students had studied a business principle in a CLIL class, this knowledge could be applied or referred to in a problem-solving activity in a speaking class, or if presentation skills are taught in one course, the guidelines and expectations could be required in a CLIL class.

\section{Acknowledgments}

The author would like to acknowledge funding from the The Teaching Reform Project of Higher Education, sponsored by Guangdong University of Foreign Studies (GWJY2017003). I also thank my colleagues-Peng Ling Ling (Linda), Hu Chun Yu (Tim), and Liu Ping, in the School of English for International Business-for their assistance in this research.

\section{References}

Airey, J. (2011). Talking about teaching in English: Swedish university lecturers' experiences of changing teaching language. Ibérica, Revista de la Asociación Europea de Lenguas para Fines Específicos, 22, 35-54. Retrieved from http://www.redalyc.org/articulo.oa?id=287023888003

Banegas, D. L. (2013). The integration of content and language as a driving force in the EFS lesson. In E. Ushioda (Ed.), International perspectives on motivation, language learning and professional challenges (pp. 82-97). Houndsmill, UK: Palgrave-Macmillan. https://doi.org/10.1057/9781137000873_5

Cai, H., Wang, M., \& Yang, Y. (2018). Teaching accounting in English in higher education-Does the language matter? English Language Teaching, 11(3), 50-59. https://doi.org/10.5539/elt.v11n3p50

Cenoz, J. (2017). The target language, the sociolinguistic and the educational context in CLIL programs. In A. Llinares, \& T. Morton (Eds.), Applied linguistics perspectives on CLIL (pp. 239-249). Amsterdam: John Benjamins. https://doi.org/10.1075/11lt.47.14cen

Costa, F., \& Coleman, J. A. (2013) A survey of English-medium instruction in Italian higher education, International Journal of Bilingual Education and Bilingualism, 16(1), 3-19. https://doi.org/10.1080/13670050.2012.676621

Costa, P. I., \& Crowther, D. (2018). Second language acquisition and world Englishes: Dialogue and engagement. World Englishes, 37, 19-23. https://doi.org/epdf/10.1111/weng.12300

Dai, G., \& Cai, Y. (2017). Application of case-task based approach in business English teaching - A case study of 
the marketing course in SEIB of GDUFS. Higher Education Studies, 7(1), 23-29. https://doi.org/10.5539/hes.v7n1p23

Dalton-Puffer, C. (2011). Content-and-language integrated learning: From practice to principles? Annual Review of Applied Linguistics, 31(1), 182-204. https://doi.org/10.1017/S0267190511000092

Dalton-Puffer, C., \& Nikula, T. (2014) Content and language integrated learning. The Language Learning Journal, 42(2), 117-122. https://doi.org/10.1080/09571736.2014.891370

Dörnyei, Z. (2002). The motivational basis of language learning tasks. In P. Robinson (Ed.), Individual differences and instructed language learning (pp. 137-158). Amsterdam: John Benjamins. https://doi.org/10.1075/11lt.2.10dor

Dörnyei, Z. (2003). Attitudes, orientations, and motivations in language learning: Advances in theory, research, and applications. Language Learning, 53, 3-32. https://doi.org/10.1111/1467-9922.53222

Dörnyei, Z. (2009). The L2 motivational self system. In Z. Dörnyei \& E. Ushioda (Eds.), Motivation, language identity and the L2 self (pp. 9-42). Clevedon: Multilingual Matters. https://doi.org/10.21832/9781847691293-003

Feng, A. (2007). Introduction. In A. Feng (Ed.), Bilingual education in China: Practices, policies, and concepts (pp. 1-12). New York: Multilingual Matters. https://doi.org/10.1007/978-3-540-68866-2_58

Georgiou, S. I. (2012). Reviewing the puzzle of CLIL. ELT Journal, 66(4), 495-504. https://doi.org/10.1093/elt/ccs047

Jensen, C., \& Thøgersen, J. (2011). Danish university lecturers' attitudes towards English as the medium of instruction. Ibérica, Revista de la Asociación Europea de Lenguas para Fines Específicos, (22), 13-33.

Léon-Henri, D. D. P. (2015) CLIL in the business English classroom: From language learning to the development of professional communication and metacognitive skills, ELT World Online.

Llinares, A., \& Morton, T. (Eds). (2017). Applied linguistics perspectives on CLIL. Amsterdam: John Benjamins. https://doi.org/10.1075/1llt.47

MacIntyre, P. D., Baker, S. C., Clément, R., \& Donovan, L. A. (2003). Sex and age effects on willingness to communicate: Anxiety, perceived competence, and L2 motivation among junior high school French immersion students. Language Learning, 53, 137-166. https://doi.org/10.1111/1467-9922.00226

Marsh, D. (2000). Using languages to learn and learning to use languages. TIE-CLIL.

Marsh, D., Pérez Cañado, M. L., \& Ráez Padilla, J. (2015). CLIL in action: Voices from the classroom. Newcastle, UK: Cambridge Scholars.

Morton, T., \& Llinares, A. (2017). Content and language integrated learning (CLIL): Type of programme or pedagogical model? In A. Llinares, \& T. Morton (Eds.). Applied linguistics perspective on CLIL. Amsterdam: John Benjamins. https://doi.org/10.1075/11lt.47.01mor

Nikula, T. (2005). English as an object and tool of study in classrooms: Interactional effects and pragmatic applications. Linguistics and Education, 16(1), 27-58. https://doi.org/10.1016/j.linged.2005.10.001

Ouyang, M., Zhu, W., \& Liu, D. (2017). Study of motives of Chinese business English development based on the theory of human capital. English Language Teaching, 10(1), 18-25.

Peng, J. E. (2007). Willingness to communicate in an L2 and integrative motivation among college students in an intensive English language program in China. University of Sydney Papers in TESOL, 2, 33-59.

Sylvén, L. S. (2017). Motivation, second language learning and CLIL. In A. Llinares, \& T. Morton (Eds.), Applied linguistics perspectives on CLIL (pp. 51-65). Amsterdam: John Benjamins. https://doi.org/10.1075/1llt.47.04syl

Ushioda, E. (2009). A person-in-context relational view of emergent motivation, self, and identity. In Z. Dörnyei \& E. Ushioda (Eds.), Motivation, language identity and the L2 self (pp. 215-228). Clevedon, UK: Multilingual Matters. https://doi.org/10.21832/9781847691293-012

Ushioda, E. (2013). International perspectives on motivation: Language learning and professional challenges. New York: Palgrave Macmillan. https://doi.org/10.1057/9781137000873

Wesely, P. M. (2009). The language learning motivation of early adolescent French immersion graduates. Foreign Language Annals, 42(2), 270-286. https://doi.org/10.1111/j.1944-9720.2009.01021.x 
Wolff, D. (2007.) CLIL: Bridging the gap between school and working life. In D. Marsh \& D. Wolff (Eds.). Diverse contexts-converging goals: CLIL in Europe, (pp. 15-25). Frankfürt: Peter Lang.

Zhu, W. Z. (2010). The theories, features and actual effect analysis of business English teaching model. Journal of Guangdong University of Foreign Studies.

Zhu, W., \& Deng, J. (2015). A case analysis of business English teacher development in China with GDUFS as an example. English Language Teaching, 8(6). https://doi.org/10.5539/elt.v8n6p159

Zhu, W., \& Wan, M. (2015). Implications of second language acquisition theory for business English teaching in current China. English Language Teaching, 8(9), 112-118. https://doi.org/10.5539/elt.v8n9p112

Zhu, W., Wu, S., \& Guo, T. (2009). Reflection into China's business English teaching practices based on GDUFS graduates' employment status. International Education Studies, 2(3), 30-33. https://doi.org/10.5539/ies.v2n3p30

Zhu, Z., Lin, L., \& Zhu, W. (2016). Research on the education system of business English courses based on the case of GDUFS. Higher Education Studies, 6(2), 127-141. https://doi.org/10.5539/hes.v6n2p127

\section{Copyrights}

Copyright for this article is retained by the author(s), with first publication rights granted to the journal.

This is an open-access article distributed under the terms and conditions of the Creative Commons Attribution license (http://creativecommons.org/licenses/by/4.0/). 